\title{
Vacuum-plasma protective coating for turbines blades
}

\author{
O. V. Sagalovich • V. V. Sagalovich • V. V. Popov • S. F. Dudnik \\ JSC «FED», Kharkiv, Ukraine
}

Received: 27 January2020 / Accepted: 24 February 2020

\begin{abstract}
Summary. The investigation of creating of nanolayer surface coatings based on Ti-TiN for turbine blades by vacuum-arc method was carried out. The influence of different methods and modes of vacuum-plasma treatment of coated surface of substrates to the adhesion value of nanolayer protective Ti - TiN coatings is studied. The best adhesion levels of the vacuum-plasma surface treatment with damage control of substrates by microarcs achieve during the treatment of substrates in the glow-discharge plasma with subsequent treatment in high-density plasma of two-stage vacuum-arc discharge and switch to Ti ions treatment were given. The optimal parameters of such a complex vacuum-plasma treatment of substrates to achieve the best adhesion of coatings are determined. The investigation with the propose of ratio definition between the thickness of the layers of Ti and TiN and the total thickness of the nanolayer coating with the value of microhardness and adhesion to the substrate was carried out. It is given that the coating has the best combination of such characteristics at a layer thickness of Ti and TiN, respectively, $2 \mathrm{~nm}$ and $8 \mathrm{~nm}$ and a total layer thickness of $15 \mu \mathrm{m}$ with an additional sublayer with a thickness of $5 \mu \mathrm{m}$. On the basis of carried out investigations the technology of coating the steam turbines blades up to $1300 \mathrm{~mm}$ long for protection against flow-accelerated corrosions is developed. The developed coatings were applied to a batch of serial blades and placed as part of a turbine for operational testing at a nuclear power plant (Paks, Hungary).

Keywords: protective coatings, titanium, titanium nitride, turbine blades, vacuum-arc methods.
\end{abstract}

The operation reliability and service life of various heat engineering equipment: turbines, steam generators, heat exchangers, valves and control valves, pumps, etc. largely depends on the degree of wear of the working surfaces of highly loaded machine elements, particularly working blades of steam turbines and compressors of gas turbine engines (GTE) and gas turbine units (GTU).

The greatest number of damage cases, that significantly reduce the service life is due to erosion, corrosion and flowaccelerated corrosion of structural materials that are in the course of operation are subjected to the simultaneous damaging effect of corrosion-erosion factors in conditions of gas-abrasive and wet-steam environment at temperatures up to 500 $540^{\circ} \mathrm{C}$, a significant dynamic and static loads [1-3].

To date, the possibility of significant increasing the equipment durability by improving the properties of structural materials, the introduction of more advanced design and technological solutions are almost exhausted.

The most effective way to improve the wear resistance of structural aterials is the use of protective coatings $[4,5]$.

Usually, in production conditions strengthening of steam turbine working steel blades is carried out by soldering of stellite (WC) plates on the leading edge or by deposition of a very hard coating in air atmosphere (supersonic and detonation sputtering).

As it was proven by operating experience, such methods are ineffective.

Soldering of the plates does not solve the erosive wear issue.

At the same time, this significantly deteriorates the aerodynamic properties and efficiency factor of the turbine.

$\triangle$ O.V. Sagalovich iht@kharkov.ua
V.V.Popov
fed@fed.com.ua

(C) The Author(s).

The article is distributed under the terms of the license CC BY 4.0. 
The coating sputtered in the air, is characterized by a weak adhesion to the substrate and low endurance due to the occurrence of oxide films.

Vacuum ion-plasma coating technology has become widespread in various branches of engineering, mainly to enhance the products durability (including erosion, corrosion and fretting resistance).

In the technological aspect has an exceptionally difficult issue of the application of the required coatings on the elements having complex configuration and a large length, and depositing of coating on the parts inner surface.

Because in most cases temper of materials of the parts coated is not allowed, depositing of vacuum-plasma coatings should not be carried out at temperatures which can reduce the base hardness, heat-treated to high hardness ( $\sim 65 \mathrm{HRC} 55)$.

No deformations and distortions are tolerated on the coated parts. Tempering temperature of steels normally used for the manufacture of parts is $200-250^{\circ} \mathrm{C}$, therefore, the technology must provide an implementation of the low-temperature coating processes, with good adhesion to the base, at temperatures at least, not exceeding $200^{\circ} \mathrm{C}$.

Preferably no additional machining should be applied to the surface after coating. In addition, the coating must provide a significant increase in the service life of the friction pair at a thickness which does not lead to going beyond the tolerances of dimensions of parts which may be only a few micrometers, and does not reduce the treatment cleanliness class of surfaces covered, which is determined by the requirements of the design documentation, as further additional machining of parts surface after manufacture is almost impossible in most cases.

It is sufficient to only mention the enormous costs - financial and technological necessary to achieve the necessary size of parts of complex configuration and large relative length with stellite coatings. [6-13].

A large number of works is known on sputtering of vacuum-plasma coatings for the protection of turbine blades

Wear-resistant and corrosion-resistant coatings can be layers of corrosion-resistant metal layers, which are repeatedly alternating, and are selected from the group consisting of molybdenum, niobium, tantalum, tungsten, chromium, titanium, zirconium, nickel or alloys based on them.

In work [7], a three-layer coating was developed, the first layer of which consists of a layer of one metal or metals alloy of 1VA or V1A groups of the Periodic Table of the Mendeleev elements formed in a neutral gas environment, the second one - in a mixture of neutral and reaction gases, and the third one - a layer of nitrides, carbides, borides or alloys thereof.

The coating contains a layer of scandium, yttrium or rare earth metal having thickness of $0.02-0.08 \mu \mathrm{m}$, the number of layers can vary from 10 to 500, the ratio thickness is $(0.02-5.0):(0.04-10):(0.1-12.5)$, the thicknesses of the first two layers have ration $1.0: 2.0: 2.5$.

Tests of these coatings revealed improved corrosion and erosion resistance of titanium blades in comparison with the resistance to erosion and corrosion without coating, but low adhesive ability significantly reduces the operational reliability of the products.

Coatings resistant to erosion, are described in [8].

They contain solid nitrided layer created on the surface of the core material and at least one hard layer obtained by PVD method, created on nitrided solid layer, in which layers of chromium nitrides, titanium nitrides, and nickel nitrides are created, which alternate with layers of nitrides of chromium/aluminum, titanium/aluminum, chromium and titanium. Such coatings improve anti-erosion properties of the surface, however, this does not always provide the necessary erosion and corrosion resistance of turbine blades during their operation under conditions of wet-steam erosion due to poor adhesion ability.

In [9] a method of coating in vacuum is describes, comprising preliminary cleaning the product surface, in which passivation-deformation treatment is performed by a flux of high-energy neutral particles before ignition. The of result passivation-deformation treatment is obtaining a high-strength coating with high density and passivity, which increases its durability significantly. But this method is more suitable for treatment of products that do not work in environments with a considerable load of erosive factors.

A method of depositing a multilayer coating on metal products by means of cathode sputtering is also known; it comprises ion cleaning and/or surface modification of products, application of at least three-layer wear-resistant coating by sputtering of the metal layer and solid solutions of gases and layers of nitride, carbide and/or borides [10] in an inert gas environment.

The method of obtaining erosion-resistant nano-layer coating for the turbo-machines blades is described in [11]. 
The coating contains nano-layers that include a metal sublayer and nano-layers of titanium nitrides [11], as well as carbides and/or titanium carbonitride, zirconium carbonitride, aluminum carbonitride, and nano-layers of these metals compounds with nitrogen and carbon, as well as the implanted ions.

Vacuum-plasma application of metal sublayer and layer based titanium nitrides, which are form during the rotation of the blades relative to their own axis, [11], and relative to consecutively located cathodes of different materials, in which their ion-implantation treatment is carried out after depositing of each layer.

The above-described technical solutions are used to protect turbine blades against salt and gas corrosion, gas-abrasive and drip-impact erosion.

These coatings increase the blades resistance to salt corrosion and drip-impact erosion by 1,5-2 times.

In [12] erosion and corrosion-resistant ion-plasma protective coatings based on titanium nitride for blades steel protection are described.

Obtaining high quality firmly joint coatings of the multilayer structure requires the good condition of surface on which the coating is deposited, as well as layers interface surfaces.

Therefore, the technological processes of the surface pre-treatment before depositing coating and in the course of coating deposition, are particularly important.

The possibility of pre-treatment of the surface with high-energy ions is the most distinguishing feature of all ionplasma technologies.

Due to the surface treatment by the high-energy particles flow it is possible to achieve modification of the materials surface properties, which usually has a positive effect on the properties of the formed coatings.

To improve the microstructure of the surface layer the new effective plasma methods of surface xomponents preparation (plasma annealing, plasma hardening, plasma modification) is used successfully.

Electrolytic-plasma polishing of parts is broadly used [[13].

In combination with surface ultrasonic treatment such combined methods of vacuum ion-plasma treatment are capable of ensuring elimination of possible deficiencies in the previous process operations to improve the cleanliness class of the surface to roughness grade $12,0.025-0.05 \mathrm{R}_{\mathrm{a}}$, which contributes to improvement of adhesion characteristics at the next deposition of vacuum-plasma coatings.

To improve operational properties of steam turbines working blades [14] multilayer nanostructured vacuum-plasma coating system of Ti-TiN system were developed using a combined vacuum ion-plasma treatment.

Processing includes pre-electrolytic-plasma surface polishing, ion-beam cleaning of the surface from oxide films, ion implantation of the surface with subsequent depositing of multilayer vacuum-plasma coating of very hard nitride compounds:

\section{Ti-TiN Zr-ZrN.}

All operations are carried out in one vacuum chamber.

Such coatings (with thickness of $40 \mu \mathrm{m}$ ) are distinguished for strong adhesion to the blades material and high corrosion and wear resistance.

We have developed vacuum-plasma methods of multistage surface pre-treatment, which, as the research results indicate, when combined with optimization of the multilayer structure allow to obtain high-quality firmly bonded coatings.

The developed process $[15,16]$, in which the deposition of a protective multilayer erosion-resistant coating in vacuum-arc deposition is performed through the multistage ion-plasma surface cleaning and formation of optimized multilayer structure of layers with predetermined repeated periods, and the thicknesses of the individual layers subject to the set programs which ensure software-synchronized pressure regulators control of inert and reaction gases and electrical process parameters.

When designing multilayer coatings it is expedient to create soft interlayers prior to deposition of hard coatings.

Soft layer improves adhesion of the coating with substrate material, ensures the presence of a large positive gradient of mechanical properties in the coating, which is a good prerequisite for normal working in conditions of friction and shock loads. These layers prevent the propagation of cracks arising in the course of operation.

This principle is used to form an optimized multilayer coating design.

The experiments were performed on the witness specimens made of steel 20X13 and titanium alloy VT6, which are used for the manufacture of blades, with the purpose of studying the different structures of coating (total coating thickness, thickness of layers, their sequence, the parameters of the stabilization annealing) with regard to the adhesion and quality of coatings, to invent optimal design of multilayer protective coating (table. 1, 2). 
The layer thickness control is performed using pre-calibrated meter thickness for FTC-2800 that allows to measure the coating growth rate from $0.01 \mathrm{~A} / \mathrm{sec}$. Applying layered coatings is carried out by setting pre-set values for nitrogen pressure that is ensured by the software-controlled nitrogen pressure regulators.

The creation of the necessary cycle schemes to obtain set recurrence intervals and thickness of the individual layers is provided by software-controlled pressure regulators of nitrogen pressure from the thickness meter FTC-2800.

To measure the temperature of the components the pyrometer Raytek is used. Metallographic examination and determination of material parameters (coating thickness, uniformity, and defect structure of the material) was performed using microscopes MMR-4 and Tesa Visio $300 \mathrm{gL}$. The coatings microhardness was measured using the PMT-3 and BUEHLER microhardness testers at a load of $50 \mathrm{~g}$.

The coatings adhesion was measured using RevetestScratchTester (RST) scratch meter.

Table 1 provides the results of the experiments performed for the choice of multilayer construction of the protective coating.

Table 1

Experiments for the choice of multilayer protective coating design

\begin{tabular}{|c|c|c|c|c|c|}
\hline NN & Substrate & \multirow{3}{*}{ NN } & \multicolumn{3}{|c|}{ First layer Ti } \\
\hline \multirow{9}{*}{1} & \multirow{9}{*}{ p. $20 \times 13$} & & \multicolumn{2}{|c|}{ Process parameters } & \multirow{2}{*}{$\begin{array}{c}\text { First layer characteristics } \\
\text { General thickness of the first layer, } \mu \mathrm{m}\end{array}$} \\
\hline & & & $\begin{array}{c}\text { current } \\
\text { Ip(Ti), } \\
\text { A }\end{array}$ & voltage Uc, B & \\
\hline & & 1.1 & 90 & 120 & $5 \mathrm{Ti}$ \\
\hline & & 1.2 . & 90 & 90 & $2 \mathrm{Ti}$ \\
\hline & & 1.3 & 120 & 100 & $3 \mathrm{Ti}$ \\
\hline & & 1.4 & 120 & 120 & $3 \mathrm{Ti}$ \\
\hline & & 1.5 & 120 & 120 & $5 \mathrm{Ti}$ \\
\hline & & 1.6 & 100 & 100 & $3 \mathrm{Ti}$ \\
\hline & & 1.7 & 120 & 140 & $5 \mathrm{Ti}$ \\
\hline \multirow{4}{*}{2} & \multirow{4}{*}{$\begin{array}{l}\text { Titanium } \\
\text { alloy BT6 }\end{array}$} & 2.1 & 90 & 120 & $5 \mathrm{Ti}$ \\
\hline & & 2.2 & 100 & 100 & $5 \mathrm{Ti}$ \\
\hline & & 2.3 & 120 & 120 & $5 \mathrm{Ti}$ \\
\hline & & 2.4 & 100 & 100 & $5 \mathrm{Ti}$ \\
\hline
\end{tabular}

Experiments for the choice of multilayer protective coating design

\begin{tabular}{|c|c|c|c|c|c|c|c|c|c|c|}
\hline \multirow{3}{*}{$\mathbf{N N}$} & \multicolumn{7}{|c|}{ Second layer Ti-TiN } & \multicolumn{3}{|c|}{ Common layer characteristics } \\
\hline & \multicolumn{3}{|c|}{ Process parameters } & \multicolumn{4}{|c|}{ Second layer characteristics Ti-TiN } & \multirow[t]{2}{*}{ Adhesion } & \multirow{2}{*}{$\begin{array}{c}\text { Total } \\
\text { thickness, } \\
\mu \mathrm{m}\end{array}$} & \multirow{2}{*}{$\begin{array}{c}\text { Microhardn } \\
\text { ess, MPa }\end{array}$} \\
\hline & $\begin{array}{c}\text { current } \\
\text { Ip(Ti), } \\
\text { A }\end{array}$ & $\begin{array}{c}\text { voltage } \\
\text { Uc,B }\end{array}$ & $\begin{array}{l}\text { nitrogen } \\
\text { pressure } \\
\mathrm{P}_{\mathrm{N} 2}, \mathrm{~Pa}\end{array}$ & $\begin{array}{c}\text { Layer } \\
\text { thickness } \\
\text { Ti, nm }\end{array}$ & $\begin{array}{l}\text { Layer thickness } \\
\text { TiN, nm }\end{array}$ & $\begin{array}{l}\text { Recurrence } \\
\text { period, } \\
\text { nm }\end{array}$ & \begin{tabular}{|c|} 
Total \\
thickness of \\
the second \\
layer, $\mu \mathrm{m}$
\end{tabular} & & & \\
\hline 1.1 & 90 & 120 & $2.0 \cdot 10^{-1}$ & & & & $10 \mathrm{TiN}$ & Good & 15 & 20,000 \\
\hline 1.2. & 100 & 90 & $2.0 \cdot 10^{-1}$ & 5 & 10 & 15 & 15 Ti-TiN & Good & 17 & 19,000 \\
\hline 1.3 & 100 & 100 & $2.0 \cdot 10^{-1}$ & 3 & 15 & 20 & 12 Ti-TiN & Good & 15 & 19000 \\
\hline 1.4 & 120 & 120 & $2.0 \cdot 10^{-1}$ & 5 & 10 & 15 & 10 Ti-TiN & Good & 13 & 19000 \\
\hline 1.5 & 120 & 120 & $2.0 \cdot 10^{-1}$ & 2 & 8 & 10 & $15 \mathrm{Ti}-\mathrm{TiN}$ & Very good & 20 & 18,000 \\
\hline 1.6 & 100 & 120 & $2.0 \cdot 10^{-1}$ & 10 & 10 & 20 & $17 \mathrm{Ti}-\mathrm{TiN}$ & Good & 20 & 17,000 \\
\hline 1.7 & 120 & 140 & $2.0 \cdot 10^{-1}$ & 10 & 20 & 20 & 20 Ti-TiN & Good & 25 & 19,000 \\
\hline 2.1 & 100 & 120 & $2.0 \cdot 10^{-1}$ & & & & $10 \mathrm{TiN}$ & Good & 15 & 20,000 \\
\hline 2.2 & 100 & 100 & $2.0 \cdot 10^{-1}$ & 10 & 10 & 10 & 15 Ti-TiN & Good & 20 & 19000 \\
\hline 2.3 & 120 & 120 & $2.0 \cdot 10^{-1}$ & 2 & 8 & 10 & 15 Ti-TiN & Very good & 20 & 18,000 \\
\hline 2.4 & 120 & 120 & $2.0 \cdot 10^{-1}$ & 15 & 20 & 20 & 15 Ti-TiN & Good & 20 & 17,000 \\
\hline
\end{tabular}

As can be seen from the table

1 , the best design of the multilayer protective coating in terms of quality, with regard to adhesion, is the construction provided in para. 
1.5 of table.

1, namely:

- erosion-resistant coating which contains a metal layer of titanium and layers of titanium nitrides, is a multi-layer structure, in which:

- a primary coating layer made of Ti with a thickness of $3-5 \mu \mathrm{m}$;

- the second layer is made as a component of the layers (Ti-TiN) with recurrence period of $10 \mathrm{~nm}$ and the thickness of the individual layers of $2 \mathrm{~nm}$ and $8 \mathrm{~nm}$ respectively, with a thickness of 10-15 $\mu \mathrm{m}$;

A process of multi-stage ion-plasma surface cleaning is performed as follows.

\section{Stage 1 - treatment in a glow discharge plasma of inert argon gas.}

Due to low values of plasma density and ion flux density on the treated surface, the speed of cleaning (sputtering of the surface layers) in the glow discharge plasma is much lower than the speed of cleaning in the plasma of electric arc discharge. Higher voltage $(600 \mathrm{~V})$ required for combustion of the glow discharge in such conditions can cause the microarcs appearance on the surface contamination and the purity class deterioration. It is not possible to completely suppress the process of the microarcs emergence, even despite the presence of a well designed system protecting against microarcs.

So the glow discharge treatment was used for the pre-degassing and 'activation' of a fairly clean surfaces with a very smooth potential increase.

The results of these studies indicate that the duration of surface treatment by argon ions in the argon glow discharge plasma should not exceed $30 \mathrm{~min}$.

The plasma parameters (ion current, ion density, current-voltage characteristics, spectral characteristics) during the ion-plasma treatment was continuously monitored and archived with plasma meter 'PlasmaMeter' and 'PlasmaSpectr' spectrometer.

Then ion-plasma processing is carried out in high-density argon gas plasma which is generated by the gas plasma generator of Avinit installation [17].

Stage 2 - processing high-density plasma of two-stage vacuum-arc discharge inert argon gas, as a powerful plasma source gas of plasma source, created by gas plasma generator for high-efficiency ion-beam treatment that provides strong adhesion of the coating to the substrate material and deposition of high-quality functional coatings.

For the implementation of the gas plasma mode at the output of the electric arc source optically opaque partition is installed which hinders the electric field effect, which is basically a louvered screen to prevent the entry of metal ions onto a part.

High-density gas plasma is excited between the cathode of the electric arc source, in proximity to which the screen is installed, and the plasma duct of the opposite electric arc source that is isolated from the vacuum chamber.

The cathode of such a discharge is a cathode of the arc discharge, isolated from the chamber with a special separator, which prevents the metal flow, but it allows to create a high-density gas plasma in the chamber.

Using the probe monitoring system of plasma technological processes plasma meter "PlasmaMeter" comparative probe measurements of plasma parameters of various plasma sources of the upgraded installation (glow, double arc discharges) were carried out. They indicated that the ratio of flows of ions and neutral atoms for dual arc discharge plasma generates approximately 300-1000 times more intense ion flux in comparison with the glow discharge.

This much denser plasma is used in the Avinit installation to clean the surface and ion assistance when depositing functional coatings.

The strength of the discharge current can virtually be arbitrary and is determined only by the thermal properties of cathode and power supply source parameters and may vary in a wide range by changing the arc current (100-200 A). The range of operating voltages discharge is $40-70 \mathrm{~V}$, at a maximum ion current density.

In ion-plasma cleaning using a high-density gas plasma, generated by gas plasma generator, there is no problem of metal particles deposition on the surface, and therefore, the potentials can be changed smoothly for parts starting from zero value. 
In this case the complete absence of electrical breakdowns in the contaminated portions of the surface is achieved in comparison with the case where a complete cleaning of the surface is provided by metal ions, and thus the original purity of the treated surface is achieved.

When working with argon, the minimum working voltage on the discharge electrodes at the maximum ion current density corresponds to a pressure of $1 \cdot 10^{-3} \mathrm{~mm} \mathrm{Hg}$. For nitrogen the optimal pressure is slightly lower and amounts to $2 \cdot 10^{-2} \mathrm{~mm} \mathrm{Hg}$.

Ion saturation current, on the magnitude of which depends the cleaning process performance, reached high values $(\sim 3 \mathrm{~A})$. The processing time in this mode varied from 10 to 15 minutes. This treatment is sufficient for transition to the mode of sputtered metal treatment by ions.

\section{Stage 3 - Ion treatment (cleaning by metal ions).}

The main process parameters during the ion treatment is ion current (ion current density), which is used to treat the product surface, the energy of ions bombarding the surface, and the treatment time.

The ion energy is adjusted by changing the accelerating voltage.

The density of ion current on the surface of the treated product is set by the ion current density of ion source that has its own regulation.

Electric arc discharge plasma treatment was started immediately after suspension of treatment in gas plasma.

Smoothly increasing the voltage supplied to the product, the parameters of the arc discharge are brought to the value set by technological process.

The mode of arc sources operation was experimentally chosen so that at continuous mode of the arc combustion the temperature of the products would rise from $573-623 \mathrm{~K}$ to $800-823 \mathrm{~K}$ while reaching the accelerating potential of $800 \mathrm{~V}$ within 8-10 min.

This made it possible to avoid the intensive creation of micro arcs, which can be caused by increased gas emission due to additional heating of the product surface and equipment during treatment, insufficient degree of pre-cleaning of the equipment and products before the chamber vacuum treatment, etc.

The stage of ion treatment can include treatment not only in pure inert gas, but also with impurities of other gases $\left(\mathrm{O}_{2}\right.$, $\mathrm{N}_{2}$ etc.), that is, to carry out plasma chemical treatment.

Table 4 shows the results of the experiments performed on the witness specimens in conditions that meet the real conditions of the proposed coating use, in order to study the effect of different stages of pre-treatment of the surface on the adhesion and quality of coatings obtained with the optimal structures provided in the previous tables. 1, 2 (para. 1.5 of table 1, para. 2 of table 2).

Table 2

Experiments to study the effect of different stages of surface pre-treatment on adhesion and coating quality

\begin{tabular}{|c|c|c|c|c|c|c|c|c|c|c|c|c|}
\hline \multirow{3}{*}{$\mathbf{N N}$} & \multicolumn{6}{|c|}{ 1.1. Treatment in glow discharge plasma: } & \multicolumn{6}{|c|}{ 1.2 Treatment in high-density argon plasma } \\
\hline & \multicolumn{3}{|c|}{ Process parameters } & \multicolumn{3}{|c|}{ Plasma characteristics } & \multicolumn{3}{|c|}{ Process parameters } & \multicolumn{3}{|c|}{ Plasma characteristics } \\
\hline & $\begin{array}{c}\text { voltage } \\
\text { Uc, B }\end{array}$ & $\begin{array}{c}\text { pressure } \\
\mathrm{Ar}_{\mathrm{N} 2} \\
\mathrm{~Pa}\end{array}$ & time, & $\begin{array}{l}\text { plasma } \\
\text { density } \\
\mathrm{n}, \mathrm{cm}^{-3}\end{array}$ & $\begin{array}{c}\text { temp. of } \\
\text { electr. } \\
\text { T, eB }\end{array}$ & $\begin{array}{l}\text { ionization } \\
\text { degree } \alpha, \\
\text { ion/atom }\end{array}$ & $\begin{array}{l}\text { current } \\
\text { Ip, A }\end{array}$ & $\begin{array}{l}\text { volt. } \\
\text { U, B }\end{array}$ & $\begin{array}{c}\text { pressure } \\
\mathrm{Ar}, \\
\mathrm{P}_{\mathrm{N} 2}, \mathrm{~Pa}\end{array}$ & $\begin{array}{c}\text { plasma } \\
\text { density } \mathrm{n} \\
\mathrm{cm}^{-3}\end{array}$ & $\begin{array}{l}\text { temp. of } \\
\text { electr. T, } \\
\text { eB }\end{array}$ & $\begin{array}{c}\text { ionization } \\
\text { degree } \\
\alpha, \text { ion/atom }\end{array}$ \\
\hline & & & & & & & & & & & & \\
\hline \multicolumn{13}{|c|}{ Glowing 1.1} \\
\hline 1.1 & 800 & $1 \cdot 10^{-1}$ & 15 & $1 \cdot 10^{7}$ & 0.1 & $10^{-7}$ & & & & & & \\
\hline 1.2. & 1,300 & $1 \cdot 10^{-1}$ & 30 & $2 \cdot 10^{7}$ & 0.15 & $10^{-7}$ & & & & & & \\
\hline & \multicolumn{12}{|c|}{ Glowing + ions Ti $1.1+1.3$} \\
\hline 1.3 & 1,300 & $1 \cdot 10^{-1}$ & 30 & $2 \cdot 10^{7}$ & 0.15 & $10^{-7}$ & & & & & & \\
\hline 1.4 & 1,300 & $1 \cdot 10^{-1}$ & 30 & $2 \cdot 10^{7}$ & 0.15 & $10^{-7}$ & & & & & & \\
\hline \multicolumn{13}{|c|}{ Glowing + DVDR + ions Ti $1.1+1.2+1.3$} \\
\hline 1.5 & 1,300 & $1 \cdot 10^{-1}$ & 30 & $2 \cdot 10^{7}$ & 0.15 & $10^{-7}$ & 100 & 100 & $1 \cdot 10^{-3}$ & $6 \cdot 10^{9}$ & 5 & $10^{-4}$ \\
\hline 1.6 & 1300 & $1 \cdot 10^{-1}$ & 30 & $2 \cdot 10^{7}$ & 0.15 & $10^{-7}$ & 120 & 200 & $1 \cdot 10^{-3}$ & $6 \cdot 10^{9}$ & 5 & $10^{-4}$ \\
\hline 1.7 & 1300 & $1 \cdot 10^{-1}$ & 30 & $2 \cdot 10^{7}$ & 0.15 & $10^{-7}$ & 120 & 500 & $1 \cdot 10^{-3}$ & $6 \cdot 10^{9}$ & 5 & $10^{-4}$ \\
\hline
\end{tabular}


Table 2 (continuation)

Experiments to study the effect of different stages of surface pre-treatment on adhesion and coating quality

\begin{tabular}{|c|c|c|c|c|c|c|c|c|c|}
\hline \multirow{3}{*}{$\mathbf{N N}$} & \multicolumn{6}{|c|}{ 1.3. Treatment with ion ions. } & \multicolumn{3}{|c|}{ Common layer characteristics } \\
\hline & \multicolumn{3}{|c|}{ Process parameters } & \multicolumn{3}{|c|}{ Plasma characteristics } & \multirow[t]{2}{*}{ Adhesion } & \multirow{2}{*}{$\begin{array}{c}\text { Total } \\
\text { thickness, } \\
\mu \mathrm{m} \\
\end{array}$} & \multirow[t]{2}{*}{ Microhardness, MPa } \\
\hline & $\begin{array}{c}\text { current } \\
\mathrm{Ip}(\mathrm{Ti}), \mathrm{A}\end{array}$ & $\begin{array}{l}\text { volt. } \\
\text { Uc, B }\end{array}$ & $\begin{array}{l}\text { time, } \\
\text { min. }\end{array}$ & $\begin{array}{c}\text { ions } \\
\text { energy } \\
\text { eB }\end{array}$ & $\begin{array}{c}\text { current } \\
\text { density } \\
\mathrm{j}, \\
\mathrm{mA} / \mathrm{cm}^{2}\end{array}$ & $\begin{array}{l}\text { time, } \\
\text { min }\end{array}$ & & & \\
\hline \multicolumn{10}{|c|}{ Glowing 1.1} \\
\hline 1.1 & & & & & & & Satisfactory & 15 & 20,000 \\
\hline 1.2 . & & & & & & & Satisfactory & 17 & 19,000 \\
\hline \multicolumn{10}{|c|}{ Glowing + ions Ti $1.1+1.3$} \\
\hline 1.3 & 100 & 90 & 10 & 300 & 0.1 & 15 & Good & 15 & 19.000 \\
\hline 1.4 & 120 & 100 & 15 & 1,000 & 0.2 & 30 & Good & 13 & 19,000 \\
\hline \multicolumn{10}{|c|}{ Glowing + DVDR + ions Ti $1.1+1.2+1.3$} \\
\hline 1.5 & 120 & 100 & 15 & $\begin{array}{ll}1,000 \\
\end{array}$ & 0.2 & 30 & Very good & 20 & 18,000 \\
\hline 1.6 & 120 & 100 & 15 & 1,000 & 0.2 & 30 & Very good & 20 & 17,000 \\
\hline 1.7 & 120 & 100 & 15 & 1,000 & 0.2 & 30 & Very good & 25 & 19,000 \\
\hline
\end{tabular}

Coating was deposited under optimal process conditions (para. 1.5 of table 1).

To improve the adhesion characteristics of the coating in the course of coating, stabilizing annealing was carried out every 50 layers at the same temperature without deposition of coating by turning off nitrogen supply and increasing the displacement potential on the parts to stop coating deposition.

The experiments we performed (Table 3) allowed us to find the optimal parameters of the stabilizing annealing process (para. 2 of table 3), which significantly improves the adhesion characteristics of the coatings obtained.

Experiments to select parameters of stabilizing annealing

Table 3

\begin{tabular}{|c|c|c|c|c|c|c|c|c|}
\hline $\mathrm{NN}$ & $\begin{array}{l}\text { Substrate } \\
\text { material }\end{array}$ & $\begin{array}{c}\text { Parameters of stabilizing } \\
\text { annealing. }\end{array}$ & \multicolumn{4}{|c|}{ Process parameters } & \multicolumn{2}{|c|}{ Common layer characteristics } \\
\hline & & & $\begin{array}{c}\text { Nitrogen } \\
\text { pressure } \\
\mathrm{P}_{\mathrm{N} 2}, \mathrm{~Pa}\end{array}$ & $\begin{array}{c}\text { Displacement } \\
\text { potential, Uc, B }\end{array}$ & $\begin{array}{l}\text { Time, } \\
\text { min. }\end{array}$ & Temperature & Adhesion & $\begin{array}{l}\text { Microhardness, } \\
\mathrm{MPa}\end{array}$ \\
\hline 1 & \multirow{4}{*}{ p. $20 \times 13$} & Every 30 layers Ti-TiN & 0 & 120 & 3 & At $T_{n}$ & Good & 18,000 \\
\hline 2 & & Every 50 layers Ti-TiN & 0 & 120 & 5 & At $T_{\Pi}$ & Very good & 18,000 \\
\hline 3 & & Every 100 layers Ti-TiN & 0 & 120 & 5 & At $T_{n}$ & Very good & 18,000 \\
\hline 4 & & Every 150 layers Ti-TiN & 0 & 120 & 5 & At $T_{\Pi}$ & Good & 18,000 \\
\hline
\end{tabular}

In the course of coating deposition stabilized annealing is performed every 50 layers at the same temperature without coating deposition by turning off nitrogen supply and increasing the displacement potential on the parts to stop coating deposition.

Carrying out process of ion-plasma purification and formation of layers with predetermined recurrence periods and thicknesses of individual layers during vacuum-arc deposition of the protective coating, is performed by programmatically set cycle schemes that provide program-synchronized control of pressure regulators of inert and reaction gas parameters.

The processes of multi-stage ion-plasma purification, subsequent vacuum-arc deposition of a protective erosionresistant coating that contains layers based on titanium nitride, and stabilizing annealing of the coating is carried out in a single vacuum chamber within a single process cycle. 
Thus, as it follows from table 1, 2, coating deposition at optimal process modes (para. 1.5 of table 1) and stabilizing annealing (para. 2 of table 2) allows to get the best results for adhesion of multilayer protective coatings, as evidenced by the lack of chipping and local sublayers.

The best results for adhesion and quality of coatings are achieved at optimal modes of the process in para. 1.5 (table 2).

It is under these conditions that deposition of erosion resistant multilayer coatings for turbine blades was carried out.

Currently we possess a unique equipment at our disposal and the technology of depositing coatings developed by us, on the complex configuration and a large length elements, as well as coating depositing on the parts inner surface.

Certain elements of our nanomaterials, nanotechnologies and equipment are unique, and protected by patents while having no analogues.

The coating deposition is carried out in the Avinit installation [17].

After all shape-generating mechanical treatments before coating deposition, standard operations of thorough degreasing in an ultrasonic bath, rinsing in petrol-acetone solvents, drying in a drying Cabinet at a temperature of $60 \mathrm{C}$ are performed.

The blade is placed in special technological tools, in a vacuum chamber of Avinit installation where vacuum of at least 2.0 $10-3 \mathrm{~Pa}$ is created.

Vacuum-plasma deposition of underlying metal is consistently preceded by three stages of treatment that include a product surface treatment in a glow discharge plasma of inert argon gas, the surface treatment in high-density plasma of two-stage vacuum-arc discharge of inert argon gas and, finally, ion-beam treatment with metal ions in accordance with optimal process modes.

Carrying out such a three-stage treatment ensures high quality surface cleaning before coatings are deposited and firmly bonded coatings are obtained.

Then a multicomponent coating is formed by vacuum arc deposition from a plasma phase in the environment of the nitrogen reaction gas with ion bombardment under optimal process modes.

Thus, Avinit structures of multilayer coatings were developed $[15,16]$, as well as equipment and technologies for their deposition on long $(1,500 \mathrm{~mm})$ and large-dimension $(100 \mathrm{~kg}$ ) parts of turbines of thermal and nuclear power plants (working blades of turbines, rails-gear wheels, shafts, etc.).

The developed coatings were deposited on a batch of steam turbines serial blades (1,300 mm long) to protect against corrosion-erosion damage.

For control purposes the witness specimens were installed in different parts of the blades - on the convex and curved surfaces, in the areas of shrouding, feather, and blade locking pieces (table 4).

The most thorough inspection of working blades with developed coatings did not reveal any damage of coatings on all sections of the blades.

Table 4

Characteristics of coatings on witness specimens located in different blade areas

\begin{tabular}{|c|c|c|c|c|c|}
\hline \multirow{2}{*}{ NN } & \multirow{2}{*}{\multicolumn{2}{|c|}{ Areas of witness specimens location }} & \multicolumn{3}{|c|}{ Common layer characteristics } \\
\hline & & & Adhesion & Total thickness, $\mu \mathrm{m}$ & Microhardness, $\mathrm{MPa}$ \\
\hline 1 & \multirow{3}{*}{$\begin{array}{l}\text { on convex } \\
\text { surfaces }\end{array}$} & $\left(L_{1}=100 \mathrm{~cm}\right)$ & Very good & 15 & 20,000 \\
\hline 2 & & $\left(L_{2}=500 \mathrm{~cm}\right)$ & Very good & 16 & 20,000 \\
\hline 3 & & $\left(L_{3}=1,000 \mathrm{~cm}\right)$ & Very good & 17 & 19,000 \\
\hline 4 & \multirow{3}{*}{$\begin{array}{l}\text { on curved } \\
\text { surfaces }\end{array}$} & $\left(L_{1}=100 \mathrm{~cm}\right)$ & Very good & 15 & 20,000 \\
\hline 5 & & $\left(L_{2}=500 \mathrm{~cm}\right)$ & Very good & 16 & 20000 \\
\hline 6 & & $\left(L_{3}=1,000 \mathrm{~cm}\right)$ & Very good & 17 & 19,000 \\
\hline 7 & \multicolumn{2}{|c|}{ in shrouding area } & Very good & 19 & 18,000 \\
\hline 8 & \multirow{2}{*}{\multicolumn{2}{|c|}{$\begin{array}{l}\text { In feather area } \\
\text { in the lock area }\end{array}$}} & Very good & 20 & 18,000 \\
\hline 9 & & & Very good & 12 & 20,000 \\
\hline
\end{tabular}

$L$ - distance from blade locking piece.

Coating was deposited under optimal process conditions (para. 1.5 of table 1, para. 2 of table 2).

According to the metallographic studies of the samples, the low-temperature $\left(\mathrm{T}<200^{\circ} \mathrm{C}\right)$ modes ensure formation of high quality cohesive coatings after the coating have been deposited. Coating deposition at temperatures not exceeding $150-200^{\circ} \mathrm{C}$ does not reduce the output surface hardness. 
The coatings microhardness has values in the range of 15,000-20,000 MPa (for Ti-N based nanocoatings).

The coatings have good adhesion to the substrate material.

No cases of coating peeling were observed when applying scratch mesh. The nanocomposite coatings had a layered structure of layers of appropriate composition with a thickness of $\sim 10-15 \mathrm{~nm}$.

Coating deposition is a finishing operation - no further refinement of the parts surface is required after manufacture.
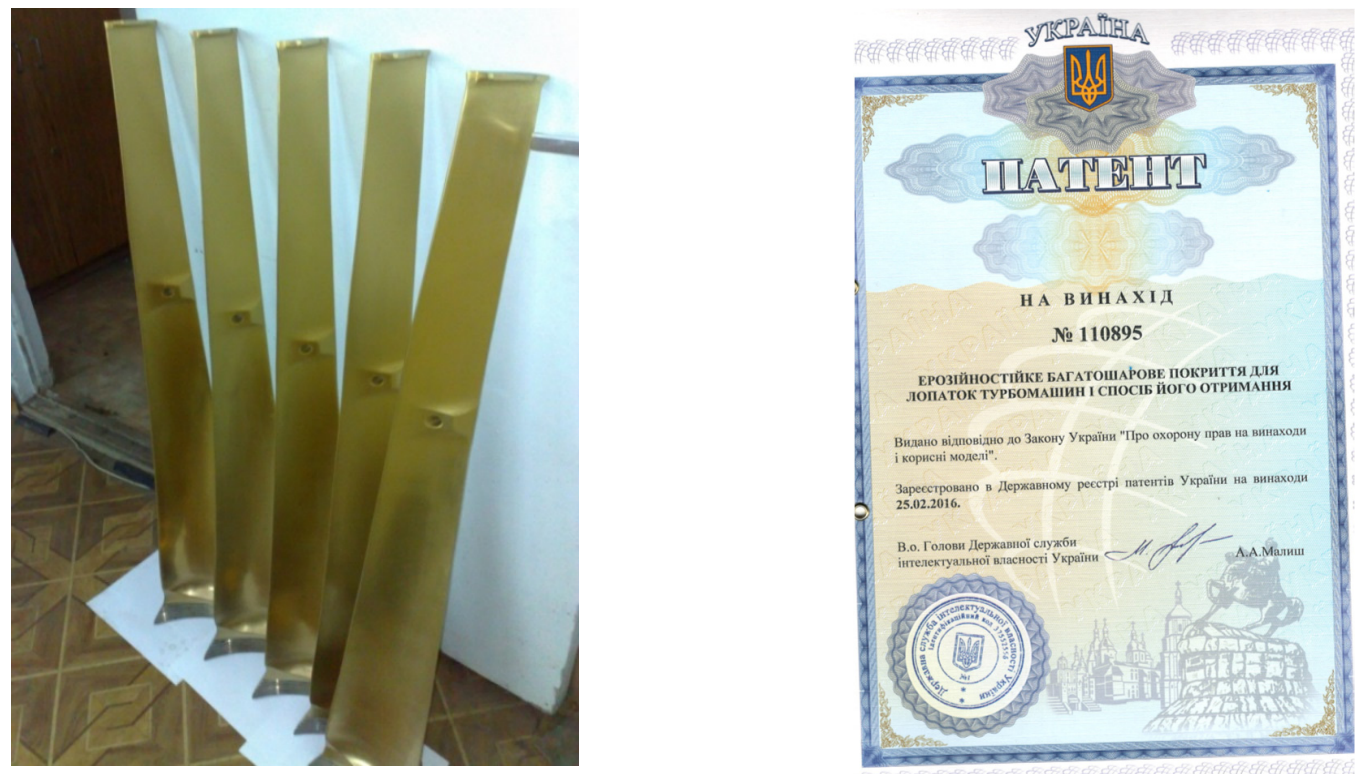

Fig. 1. Turbine blades with developed protective coating using new complex plasma chemical nanotechnologies and equipment (1,300 $\mathrm{mm}$ long)

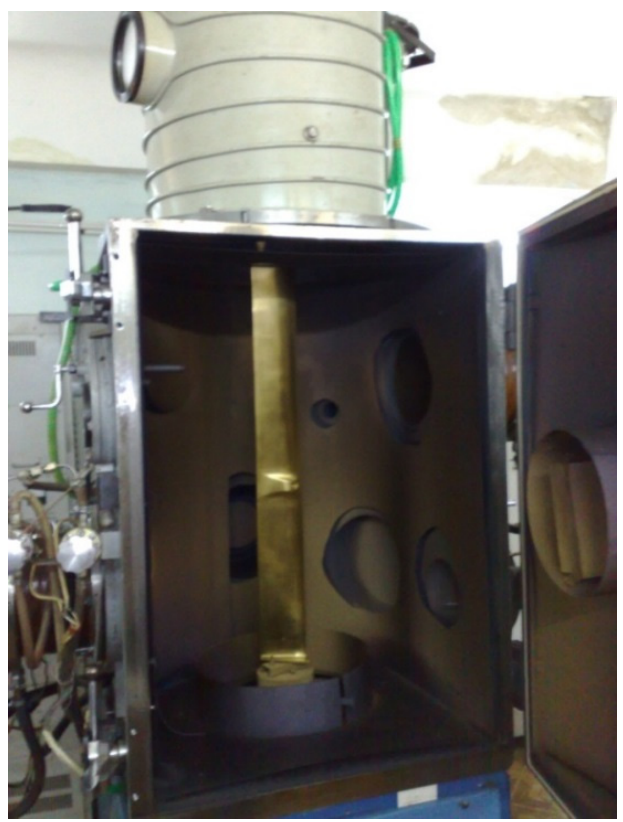

Fig. 2. Turbine blades in the course of coating deposition

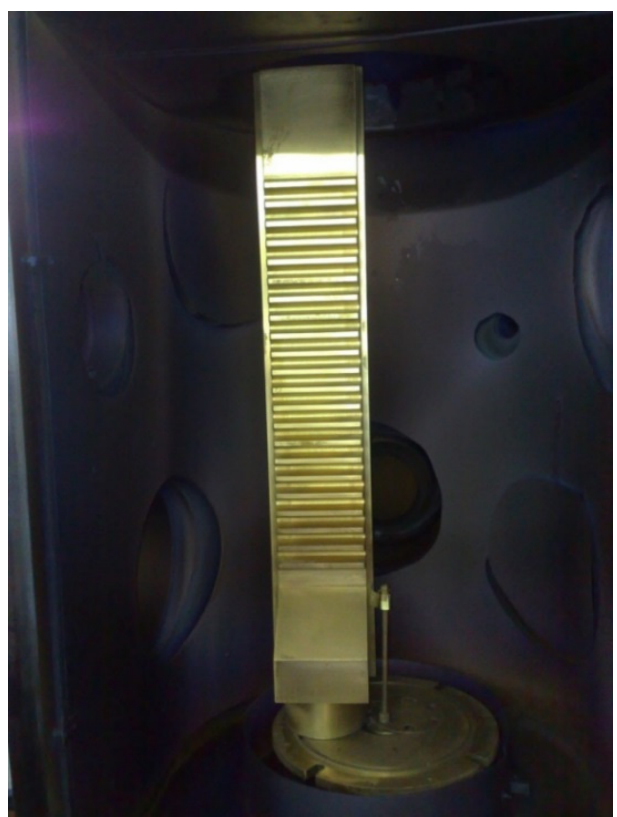

Fig. 3. Turbine rail tooth gear with protective coating (length $-1,000 \mathrm{~mm}$, weight $-70 \mathrm{~kg}$ )

A batch of blades with developed coatings (fig. 1) installed as a part of the turbine for operational testing at NPP (Paksi, Hungary). 


\title{
References
}

1. Акользин, П. А. Коррозия и защита металла теплоэнергетического оборудования / П. А. Акользин. - Энергоиздат, 1982.

2. Пряхин, В. А. Проблемы эрозии рабочих лопаток паровых турбин / В.А Пряхин, О. А Поваров, В. А Рыженков // Теплоэнергетика, - 1984. - № 10.

3. Явельский, М. Б. Эрозия выходных кромок рабочих лопаток и мероприятия по ее устранению / М. Б. Явельский, Ю. П Шилин. - Энергомашиностроение, 1981.

4. Селезнёв, Л. И. Оценка длительности инкубационного периода эрозионного износа / Л. И. Селезнёв, В. А. Рыженков // Технология металлов, - 2007. - № 3.

5. Рыженков, В. А. Исследование антикоррозионных свойств износостойких покрытий для защиты рабочих лопаток паровых турбин мощных энергоблоков / В. А. Рыженков, С. Н. Погорелов, С. И. Нефедин // Вестник МЭИ, - 2001. - № 5.

6. Крайнов, В. К. Повышение ресурса работы теплотехнического оборудования ТЭС на основе применения износостойких защитных покрытий / В. К. Крайнов // Общие вопросы электроэнергетики, - 2002. - № 2.

7. Pat RU № 2161661, М. Кл. С23C 14/16, опубл. 10.01.2001.

8. Патентна заявка США № 2009/0123737, М.кл. С23С М.кл. С23С 14/06, 14/48, опубл.14.05.2009 г.

9. Pat RU № 2061788, М.кл. С23C 14/06.

10. $\quad$ Pat RU № 2228387, М.кл. С23C 14/06.

11. Pat RU № 2390578, М.кл. С23C 14/06, 14/48; опубл.12.11.2007 г.

12. Рыженков, В. А. Исследование износостойких защитных покрытий на основе нитрида титана / В. А. Рыженков, С. Б. Нестеров, С. Н. Погорелов // Тр. шестой научно-технической конференции. "Вакуумная наука и техника". - Гурзуф. 1999.

13. Смыслов, А. М. Многоэтапная электролитно-плазменная обработка изделий из титана и титановых сплавов / А. М. Смыслов, М. К. Смыслова, А. Д. Мингажев, К. С. Селиванов // Вестник УГАТУ. Машиностроение. Технология и оборудование физ. техн. обработки. - 2009. - Т. 13, - № 1. - С. 141-145.

14. Смыслов, А. М. Разработка и исследование технологических методов повышения фреттинг-стойкости рабочих лопаток из титановых сплавов / А. М. Смыслов, К. С. Селиванов // Вестник УГАТУ Технология машиностроения. - 2007. - Т. 9, - №1 (19). - C. 77-83.

15. Пат. 99816 Україна, МПК С23С 14/00 (2015.01). Спосіб отримання ерозійностійкого багатошарового покриття для лопаток турбомашин / Сагалович О. В., Сагалович В. В.; винахідники та власники - автори. - № u 2014 14066; заявл. 29.12.2014; опубл. 25.06.2015, Бюл. № 12. - 4 c.

16. Сагалович О.В., Сагалович В.В., Ерозійностійке багатошарове покриття для лопаток турбомашин і спосіб його отримання. Рat UA 110895 від 25.02.16.

17. Сагалович О.В. Установка Avinit для нанесення багатошарових функціональних покриттів / О.В. Сагалович, В.В. Сагалович, В.В. Попов та ін. // Физическая инженерия поверхности. - 2010. - Т. 8. - С. 336-347.

\section{Вакуум-плазменные защитные покрытия для лопаток турбин}

\author{
А. В. Сагалович, В. В. Сагалович, В. В. Попов, С. Ф. Дудник
}

Аннотация. Проведены исследования по получению вакуум-дуговым методом нанослойных защитных покрытий на основе Ті TiN для лопаток турбин. Изучено влияние различных методов и режимов вакуум - плазменной обработки поверхности покрываемых подложек на величину адгезии нанослойных защитных покрытий Ti - TiN. Показано, что наилучшие показатели адгезии при вакуум - плазменной обработке поверхности с предотвращением повреждения подложек микродугами достигаются при обработке подложек в плазме тлеющего разряда с последующей обработкой в высокоплотной плазме двухступенчатого вакуум-дугового разряда и перехода к обработке ионами Ті. Определены оптимальные параметры такой комплексной вакуум-плазменной обработки подложек для достижения наилучших показателей адгезии покрытий. Проведень исследования с иелью определения оптимального соотношения толщиины слоев Ti и TiN и общей толщины нанослойного покрытия на величину микротвердости и адгезии к подложке. Показано, что покрытие обладает наилучшим сочетанием таких характеристик при толщине слоев Ti и TiN, соответственно, 2 нм и 8 нм и общей толщине слоя 15 мкм с дополнительным подслоем из Ті толщиной 5 мкм. На основании проведенных исследований отработана технология нанесения покрытий на лопатки паровых турбин длиной до 1300 мм для защитьл от коррозионно-эрозионных повреждений. Разработанные покрытия были нанесены на партию серийных рабочих лопаток и поставлены в составе турбины на эксплуатационные испытания на АЭС (Паки, Венгрия).

Ключевые слова: защитные покрытия, титан, нитрид титана, лопатки турбин, вакуум-дуговые методы. 


\title{
Вакуум-плазмові захисні покриття для лопаток турбін
}

\author{
О. В. Сагалович, В. В. Сагалович, В. В. Попов, С. Ф. Дуднік
}

Анотація. Проведено дослідження по отриманню вакуум-дуговим методом наношарових захисних покриттів на основі Ті - Тіл для лопаток турбін. Вивчено вплив різних методів $і$ режимів вакуум - плазмової обробки поверхні підкладинок, ццо покриваються, на величину адгезї наношарових захисних покриттів Ti - ТіN. Показано, щзо найкращзі показники адгезї при вакуум - плазмовій обробиі поверхні із запобіганням пошкодження підкладинок мікродугами досягаються при обробиі підкладинок в плазмі тліючого розряду з подальшою обробкою в високошільній плазмі двоступеневого вакуум-дугового розряду $і$ переходу до обробки іонами Ті. Визначено оптимальні параметри такої комплексної вакуум-плазмової обробки підкладинок для досягнення найкращих показників адгезї покриттів. Проведено дослідження з метою визначення оптимального співвідношення товщзини шарів Ti i TiN $i$ загальної товщчини наношарового покриття на величину мікротвердості й адгезї̈ до підкладинки. Показано, щуо покриття має найкраще поєднанням таких характеристик при товщині шарів Ті $і$ TіN, відповідно, 2 нм $і$ н нм $i$ загальній товщині шару 15 мкм з додатковим підшаром з Ті товщиною 5 мкм. На підставі проведених досліджень відпрацьовано технологію нанесення покриттів на лопатки парових турбін довжиною до 1300 мм для захисту від корозійноерозійних пошкоджень. Розроблені покриття були нанесені на партію серійних робочих лопаток $і$ поставлені в складі турбіни на експлуатаційні випробування на АЕС (Паки, Угорщчина).

Ключові слова: захисні покриття, титан, нітрид титану, лопатки турбін, вакуум-дугові методи.

\section{References}

1. Akolzin, P.A. (1982), Corrosion and metal protection of heat power equipment, Energoizdat.

2. Pryakhin, V.A. Povarov, O.A. and Ryzhenkov, V.A. (1984), Issues of steam turbines' working blades erosion, Thermal power generation, no. 10.

3. Yavelsky, M.B. and Shilin, Yu.P. (1981), Erosion of rotary blades exit edges and actions to remove it, Energomashinostroyenie.

4. Seleznyov, L.I. and Ryzhenkov, V.A (2007), Evaluation of the duration of the erosion wear incubation time, Technology of metals, no. 3 .

5. Ryzhenkov, V.A., Pogorelov, S.N. and Nefedin, S.I. (2001), The study of the anticorrosive properties of wear-resistant coatings to protect the working blades of high-capacity power generation units steam turbines, MEI Bulletin, no. 5.

6. Krainov, V.K. (2002), Increasing the service life of TPP thermal equipment based on the use of wear-resistant protective coatings, General issue of power generation, no. 2.

7. PatRU No. 2161661, M. Kl. C23C 14/16, published 01/10/2001.

8. USA patent claim No. 2009/0123737, M.kl. C23C M.kl. C23C 14/06, 14/48, published 05/14/2009.

9. $\quad$ Pat RU No. 2061788, M.kl. C23C 14/06

10. Pat RU No. 2228387, M.kl. C23C 14/06

11. Pat RU No. 2390578, M.kl. C23C 14/06, 14/48; published 11/12/2007.

12. Ryzhenkov, V.A. S.B. Nesterov, S.N. Pogorelov (1999), The study of wear-resistant protective coatings based on titanium nitride, Proceedings of the sixth research-technological conference, Vacuum science and technology, Gurzuf, Ukraine.

13. Smyslov, A.M. Smyslova, M.K. Mingazhev, A.D. and Selivanov, K.S. (2009), Multi-stage electrolyte-plasma processing of products from titanium and titanium alloys, Bulletin of UGATU Mashinostroyenie (Machinebuilding), Technology and equipment of physical and technological treatment, vol. 13, no. 1, pp. 141-145.

14. Smyslov, A.M. and Selivanov, K.S. (2007), Development and study of technological methods for increasing the fretting resistance of working blades made of titanium alloys, Bulletin of UGATU Machinebuilding technology, vol. 9, no. 1 (19), pp. 77-83.

15. Sagalovich, O.V. and Sagalovich, V.V. Pat. 99816 Ukraine, MPK C23C 14/00 (2015.01), The method for obtaining erosionresistant multilayer coating for turbine machines blades, inventors and owners - authors. No. u 2014 14066; appl. 29.12.2014; published 25.06.2015, Bull. no. 12.

16. Sagalovich, O.V. Sagalovich. V.V. Erosion-resistant multilayer coating for turbine blades and the method for its obtaining. PatUA 110895 dated 25.02.16.

17. Sagalovich, O.V., Sagalovich, V.V. and Dudnik, S.F. et al. (2010), Avinit installation for depositing multilayer functional coatings, Physical engineering of the surface, vol. 8, pp. 336-347. 